\title{
Study on the "Going-out" Business Mode of Chinese Enterprise
}

\author{
Xiao Wang \\ Department of Management Engineering \\ Henan Mechanical and Electrical Engineering College \\ Xinxiang 453002, China \\ Tel: 86-373-3206-611_E-mail: 963-163@163.COM
}

\begin{abstract}
"Going-out" is an inevitable way for Chinese enterprises going abroad. Firstly this paper introduces the popular operations of world enterprises going out. Then, by analyzing some successful Chinese enterprises, this paper makes deep studies on certain enterprises. Finally, this paper summarizes four modes and puts forward a business mode that is right for most Chinese enterprises.
\end{abstract}

Keywords: Enterprise "going-out", International operation, Enterprise case, Business mode

Economic globalization is the dominant trend of the world today, which brings about significant commodity and production flows. No matter where it is one country or one region, they completely realize that all countries and regions must participate in the economic globalization in order to achieve fact economic development. Practices repetitively prove that the globalization brings about chances of fast development for developing countries. In 2007, the Seventeenth National Congress of the Communist Party of China definitely declares: "Insist on the primary policy of reform and opening-up; integrate 'bringing-in' with 'going-out' properly; enlarge opening-up fields, optimize opening-up structure, and improve opening-up quality; perfect the open economic system that emphasizes on mutual connections and interests, safety, and high efficiency; cultivate new advantages in global economic cooperation and competition under the economic globalization." An enterprise "going-out" firstly should select an appropriate business operation mode based on self characteristics. Then, guided by the mode, an enterprise can perform international operations.

What is "going-out"? It refers to a process of an enterprise stepping out of domestic market and entering world market. It includes foreign trade, foreign investment, export of labor service, and foreign contracting. What is "going-out" business mode? It refers to former successful experiences and operations of enterprises in international operations. Enterprises may copy or take references from these experiences and operations according to self characteristics. Experiences and operations are different for enterprises. We can summarize some modes for later references. Here, we probe into the "going-out" mode of some successful enterprises in China.

\section{The popular mode of an enterprise entering the world market}

\subsection{The export trade mode}

The export trade mode is a traditional way for an enterprise entering world market, and also a junior method for an enterprise exploring world market. This mode includes these specific methods as follow.

(1) Direct export. (2) Indirect export. (3) Order production.

\subsection{The foreign Direct Investment (non-capital) operational mode}

Foreign direct investment means enterprises enter world market by directly investing in other countries and establishing enterprises overseas. This mode includes these specific methods as follow.

(1) Form child enterprises in foreign countries. (2) Cooperative business. (3) Overseas sell. (4) Build up enterprises overseas.

\subsection{The capital operation mode}

The capital operation means an enterprise explores foreign market by acquiring foreign enterprises' large proportion of shares based on its advantages in capitals, brands, and technologies. This mode includes specific methods as follow.

(1) Overseas listing. (2) Merge and purchase foreign enterprises. (3) Form joint enterprises.

\section{Successful cases of Chinese enterprises "going-out" business mode}

Since the execution of reform and opening-up policy, Chinese enterprises explore proper successful ways for 
transnational operations gradually. Although specific way is different, most follow or adopt the primary international business mode more or less. In order to summarize experiences and find out the law, we firstly sum up the international business modes adopted by Chinese enterprises.

\subsection{The international business mode of TCL}

TCL is founded in 1981. After establishing its position in domestic market, it begins to export products in 1985 . In early 1999, TCL takes the first step toward international operations. It invests one hundred million RMB in Vietnam and builds a production enterprise. Soon after, it secures its position in market and the market share reaches $12 \%$. Afterwards, TCL begins to expand toward countries around Vietnam ------ other Southeast Asia countries. It builds up production basis in Indonesia, Malaysia, and other ASEAN (Association of South East Asian Nations) countries. After achieving success in the basis, TCL merges a brand enterprise of developed country in 2002. It purchases Schneider Electric, a hundred- year Germany enterprise, at a price of 8.2 million Euro and successfully makes best use of its brand, production equipments, $\mathrm{R} \& \mathrm{D}$ institutions, and marketing channels, completing the signalized step of mature transnational enterprise toward transnational capital operation. (Source: TCL website)

The success of TCL is based on three steps. Firstly, it establishes its position in domestic market. After possessing the brand competitiveness and business strengths, it exports products. Secondly, it produces products in or exports products to developing countries and regions where the production and technology lagged behind. Thirdly, as it possesses enough capitals, it performs enterprise merger and purchase, what is in accordance with mature transnational enterprise's business strategy. Before this stage, TCL has already accomplished multiple operations successfully in domestic market, what establishes firm basis for realizing multi-brand strategy. When Mr. Dong Li, the director of the board, evaluates the Europe purchase strategy, he said: "Schneider Electric can provide us with a complete set of services in European information, retail, and supply by its influences and strengths. It is faster than us promoting the brand by ourselves."

The international business mode of TCL is displayed in Figure 1 as follow.

\subsection{The international business mode of Skyworth Group}

Skyworth Group enters the color TV industry in 1991. From 1995 to 1998, it exports the largest amount of color TV to 85 countries and regions, and builds up distribution relationship with more than 3000 overseas distributors and retailers, forming an international marketing net. In 1999, Skyworth Group sets up a laboratory in Silicon Valley, USA. In Aug. 1999, it gets 30 million Dollar investment from Europe ING Group, Switzerland Value Partner Group, and American Walton International Investment Group (China Funds), which accounts for 15\% of capital stock. As the shareholders of Skyworth Group, the three groups offer technological information to support its international operations periodically. Afterwards, Skyworth Group builds up TV production bases in Mexico and Malaysia, and sets up technology research center, what serve as important preconditions for large-scale transnational merge and purchase. In Apr. 2000, Skyworth Digital Holding Limited goes public in Hongkong and collects hundreds of millions of Hongkong dollars. (Source: Skyworth Group website)

The international business mode of Skyworth Group is displayed in Figure 2 as follow.

\subsection{The international business mode of Lenovo}

The Lenovo Group is founded in 1984. After accomplishing initial accumulation, in Apr. 1988 it combines with the Institute of Computer of China Academy of Sciences and Hongkong DAW Computer Systems Limited, and creates the Hongkong Legend Computer Limited Company. In 1988, it realizes the sales of 120 million Konghong dollars. In Apr. 1989, it founds the Legend Group and establishes the international business strategy, starting to explore the world market actively. Since 1990, it sets up branches or offices in Los Angeles of America, German, and Singapore. In Feb. 1994, Hongkong Legend Holding Limited Company goes public in Hongkong. At the same year, it sets up the R\&D base in Silicon Valley of America. The international business of Lenovo follows three procedures. Firstly, it founds a trade company overseas. Secondly, it sets up a research-production-sale integrated transnational company. Lenovo has basically accomplished the two procedures in 1994 and pursues for further development. Thirdly, it enlarges its scale and grows into a world large transnational company. In May 2005, it purchases the personal computer branch of IBM. In 2004, it becomes the first Chinese company that cooperates with the International Olympic Committee. The Lenovo Group has offered computers, computing technology facilities, and funds exclusively for the 2006 Winter Olympics and the 2008 Beijing Olympics. (Source: Lenovo Group website)

The international business mode of Lenovo Group is displayed in Figure 3 as follow.

\subsection{The international business mode of Zhejiang private SME (small and medium-sized enterprise)}

Since the execution of reform and opening-up policy, Zhejiang private SMEs have achieved fast development. Some workshops and village clusters at the very beginning gradually develop into specialized industrial enterprise clusters centered on towns and cities, such as Yongkang hardware, and Wenzhou lighter, and other small electric facility and commodity market clusters. These regional markets gradually evolve into an international market. For example, 
Wal-mart, Carrefour, and some world well-known companies make purchases in Zhejiang market. There are hundreds of foreign permanent purchasing institutions. Everyday more than four and five thousand foreign business men purchase sorts of commodities here. However, Zhejiang people do not satisfy with the achievements. They look for greater opportunities overseas from these foreign business men. Especially for bosses of production enterprises and some distributors, they extend their market into East Europe, South America, Africa, and Southeast Asia step by step. One leader has said proudly: "Today, where there is human being, there are Zhejiang business men." (Source: Zhejiang SME website, etc.)

The international business mode of Zhejiang private SME is displayed in Figure 4 as follow.

\section{The analysis of Chinese enterprises' "going out" international business mode}

Although successful Chinese enterprises perform international business differently, they have some similarities more or less. In order to make deep analysis, we list some important measures of the four modes as follow.

See Table 1. It shows the measures adopted by Chinese enterprises in international operations.

According to this table, firstly all enterprises choose to perform export trade in international business. After possessing the base of export trade, they start to explore international distribution channels. Secondly, TCL and Lenovo Group develop quickly and timely in international business. Besides, they start at a higher level by cooperating with international enterprises. TCL and Lenovo Group set up overseas branches and distribution channels respectively in late 80s and early 90s. Thirdly, they go public overseas early and choose to purchase large and influential foreign enterprises. Fourthly, although Skyworth Group starts later than TCL and Lenovo Group in international operations, it has thousands of overseas partners in distribution. Finally, Zhejiang SME cluster stabilizes its competence in domestic market by rich products, high qualities, and low prices. It attracts amounts of overseas purchasers. Then it steps out of China and sets up specialized market abroad. By this way, it turns into a new mode of SME cluster international operations.

As for the similarities, all start from exports. During the process of exporting products, enterprises gradually familiarize with international transaction principles, and accumulate experiences. Afterwards, the three modes develop differently. TCL gives priority to explore markets in developing countries. It chooses to produce and sell its mature products in developing countries. Skyworth Group builds up distribution channels in international market and forms a marketing network. Lenovo Group sets up overseas branches and performs transnational merger and purchase, and realizes financing by listing.

As enterprises adopt these four modes, they should take products characteristics and their strengths into consideration, and the comparative advantages and competitive advantages should not be ignored. For example, TCL builds up enterprises in Southeast Asia, what is rightly in accordance with its product characteristics and the theory of product life cycle. In China, TV and some electric products tend to be saturated. But in some developing countries, the demand for TV is large. Southeast Asia countries are mostly at the developing stage. Therefore, many enterprises follow this mode, using China's mature products to win market shares in Southeast Asia countries, and achieve successes. This mode is right for most Chinese enterprises' "going out". Lots of Chinese enterprises succeed by this way, such as Luoyang Northern Ek Chor Motorcyle Co. Ltd. In mid 1990, it begins to export products to Southeast Asia countries. Then select proper areas to build up enterprises there. In 2002, it exports amounts of products to Japan (Source: Luoyang Northern Ek Chor Motorcycle Co. website). Afterwards, only when it operates as TCL in international business, can it turns into a greater and stronger transnational company.

Chinese enterprises can also take references from Skyworth Group in international operations. Due to the severe competition in domestic market, Skyworth Group starts cooperation with foreign distributors early. Till mid and late 90s, it has already developed cooperative relationships with more than 3000 foreign wholesalers and distributors. Recently, a popular saying in marketing field is that "the terminal controls". Skyworth Group can apply its "terminal" strategy early, what shows its foresight completely. Because Skyworth Group controls lots of distributors in international market, it can manage its business well in international operations. In contrast, some enterprises just depend on one or two trade companies in international operations. Once world economic situations change, these enterprises may face serious risks. In a sense, Skyworth Group masters its international operations. Both Xinfei Electric Appliance Company and Skyworth Group produce family electric appliances. The export strategy of Xinfei Electric Appliance Company is similar to that of Skyworth Group. In early 90s, Xinfei advances the three-step strategy for international operations. The first step is to "launch out by borrowing ships". The second step is to set up overseas offices. The third step is to build up enterprises abroad. In 1999, Xinfei cooperates with General Electric, one of world top 500 enterprises, and exports products to United States of America. In 2003, its exports reach the top, realizing the first step of the strategy. However, the second step is hard and does not achieve progresses. Xinfei exports products mostly by depending on trade companies or exports products indirectly. The amount of exports is huge, but the effect is worse. Recently, Xinfei recognizes its defects. It enhances its brand construction and begins to export products with self-owned brand. As a 
result, Xinfei has already developed well in Mongolia, Nigeria, and other countries in Asia and Africa. Guided by the new business strategy, Xinfei Electric Appliance Company will achieve greater successes in future. (Source: Xinfei Electric Appliance website)

\section{References}

Ma, Chunguang. (2002). International Enterprise Management (1st Edition). Beijing: University of International Business and Economics Press. Jan.

Neal Hood. (1990). Transnational Enterprise Economics (1st Edition). Beijing: Economic Science Press. Oct.

Xue, Rongjiu. (1997). World Trade Organization and China's Extensive Trade Development (1st Edition). Beijing: University of International Business and Economics Press. June.

Zhang, Youwen. (2001). A Survey of World Economy. Beijing: Higher Education Press. July.

Table 1. The measures adopted by Chinese enterprises in international operations

\begin{tabular}{|c|c|c|c|c|c|c|c|c|c|}
\hline & \multirow[t]{2}{*}{ Export } & \multicolumn{4}{|c|}{ Foreign direct investment } & \multicolumn{3}{|c|}{ Capital operation } & \multirow[t]{2}{*}{ other } \\
\hline & & $\begin{array}{c}\text { Child } \\
\text { company }\end{array}$ & $\begin{array}{l}\text { Coop } \\
\text { erativ } \\
\text { e } \\
\text { produ } \\
\text { ction }\end{array}$ & distribution & $\begin{array}{l}\text { Build } \\
\text { up } \\
\text { comp } \\
\text { anies }\end{array}$ & $\begin{array}{c}\text { Overs } \\
\text { eas } \\
\text { listing }\end{array}$ & $\begin{array}{l}\text { Merger } \\
\text { and } \\
\text { purchase }\end{array}$ & $\begin{array}{c}\text { Joint } \\
\text { venture }\end{array}$ & \\
\hline TCL & Late $80 \mathrm{~s}$ & $\begin{array}{c}\text { Hongkong } \\
\text { child } \\
\text { company } \\
\text { in } 1993\end{array}$ & $\begin{array}{c}\text { Coop } \\
\text { erate } \\
\text { with } \\
\text { Taiwa } \\
\text { n } \\
\text { Rechi } \\
\text { in } \\
2001\end{array}$ & $\begin{array}{c}\text { In charge of } \\
\text { overseas } \\
\text { sales in } \\
1993\end{array}$ & $\begin{array}{c}\text { Build } \\
\text { up } \\
\text { comp } \\
\text { anies } \\
\text { in } \\
\text { South } \\
\text { east } \\
\text { Asia } \\
\text { in } \\
1999\end{array}$ & $\begin{array}{c}\text { Go } \\
\text { public } \\
\text { in } \\
\text { Hong } \\
\text { kong } \\
\text { in } \\
1999\end{array}$ & $\begin{array}{l}\text { Merge } \\
\text { Hongkong } \\
\text { Luks in } \\
1996\end{array}$ & $\begin{array}{c}\text { Joint } \\
\text { venture } \\
\text { with } \\
\text { French } \\
\text { Thompe } \\
\text { on in } \\
2003\end{array}$ & \\
\hline $\begin{array}{c}\text { Skyw } \\
\text { orth } \\
\text { Grou } \\
\text { p }\end{array}$ & Mid 90s & & & $\begin{array}{l}\text { Cooperate } \\
\text { with more } \\
\text { than } 3000 \\
\text { foreign } \\
\text { distributors } \\
\text { in } 1998\end{array}$ & $\begin{array}{c}\text { Set } \\
\text { up a } \\
\text { lab in } \\
\text { Silico } \\
\text { n } \\
\text { Valle } \\
\text { y in } \\
1999\end{array}$ & $\begin{array}{c}\text { Go } \\
\text { public } \\
\text { in } \\
\text { Hong } \\
\text { kong } \\
\text { in } \\
2000\end{array}$ & & $\begin{array}{c}\text { Gets } \\
\text { investm } \\
\text { ents } \\
\text { from } \\
\text { Europe } \\
\text { ING } \\
\text { Group } \\
\text { and } \\
\text { other } \\
\text { groups } \\
\text { in } 1999\end{array}$ & \\
\hline $\begin{array}{c}\text { Leno } \\
\text { vo }\end{array}$ & Late $80 \mathrm{~s}$ & $\begin{array}{l}\text { Set up } \\
\text { Hongkong } \\
\text { Legend } \\
\text { Computer } \\
\text { Limited } \\
\text { Company } \\
\text { in } 1988\end{array}$ & & $\begin{array}{c}\text { Set up } \\
\text { branches in } \\
\text { Los Angeles } \\
\text { in } 1990\end{array}$ & & $\begin{array}{c}\text { Go } \\
\text { public } \\
\text { in } \\
\text { Hong } \\
\text { kong } \\
\text { in } \\
1994\end{array}$ & $\begin{array}{l}\text { Purchase } \\
\text { the } \\
\text { personal } \\
\text { computer } \\
\text { branch of } \\
\text { IBM in } \\
2005\end{array}$ & & $\begin{array}{l}\text { Partn } \\
\text { er of } \\
2008 \\
\text { Beijin } \\
\text { g } \\
\text { Olym } \\
\text { pics }\end{array}$ \\
\hline $\begin{array}{l}\text { Zheji } \\
\text { ang } \\
\text { SME }\end{array}$ & $\begin{array}{l}\text { Purchas } \\
\text { ers } \\
\text { come } \\
\text { Zhejian } \\
\text { g in late } \\
\text { 80s }\end{array}$ & & & $\begin{array}{l}\text { Set up } \\
\text { specialized } \\
\text { markets } \\
\text { overseas in } \\
\text { mid 90s }\end{array}$ & & & & & \\
\hline
\end{tabular}

Source: the websites of TCL, Skyworth Group, and Lenovo, and relevant journals 


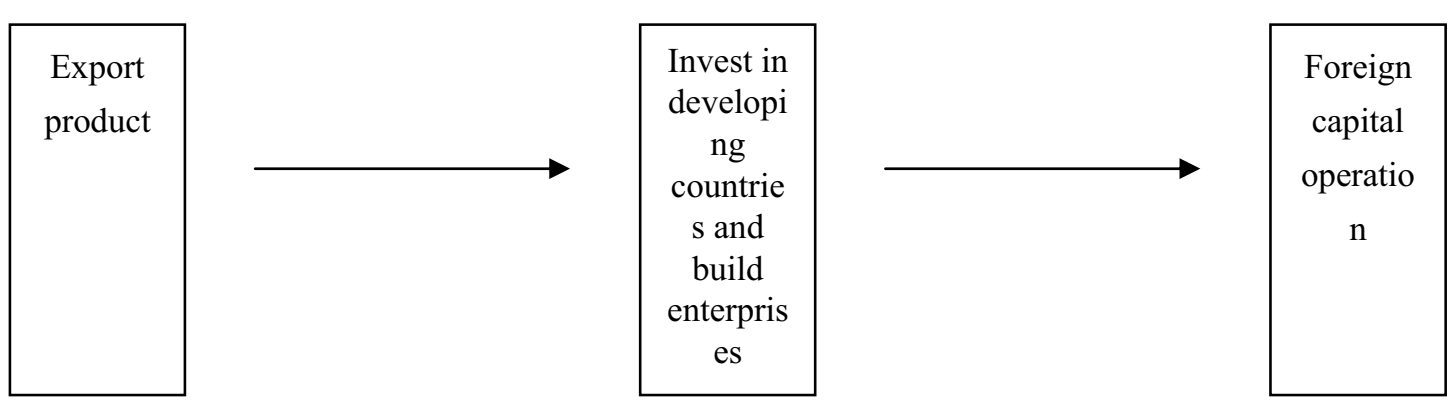

Figure 1. The International Business Mode of TCL

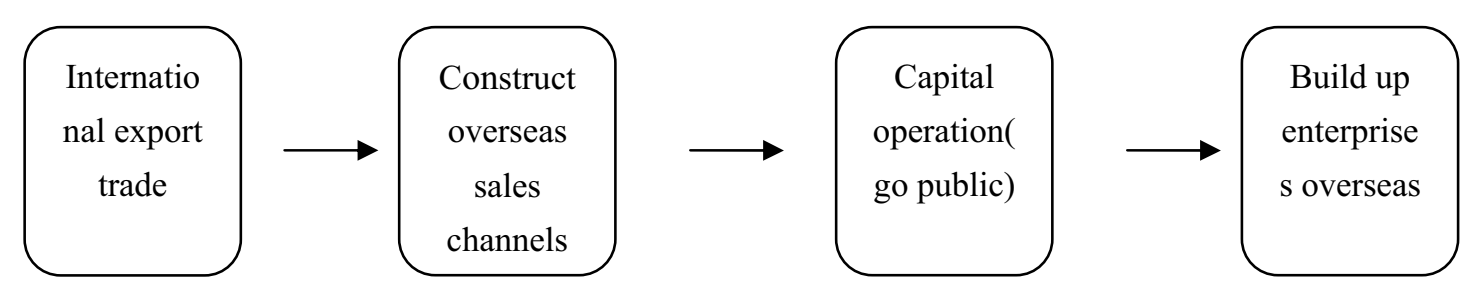

Figure 2. The International Business Mode of Skyworth Group

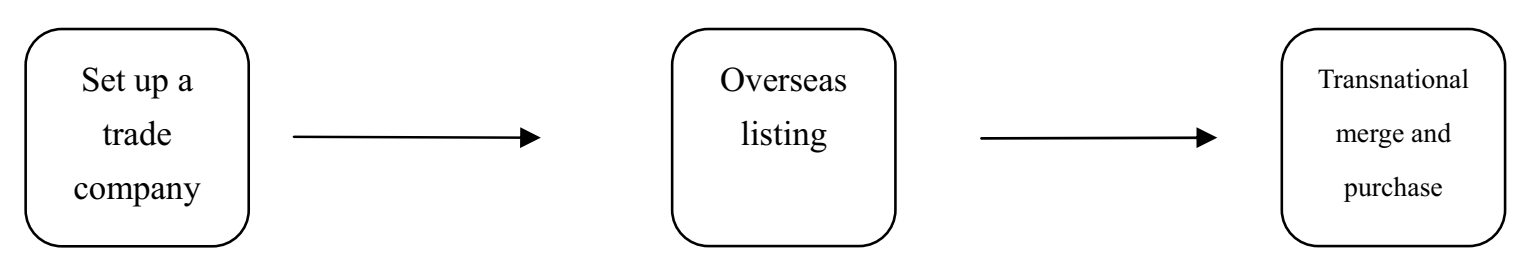

Figure 3. The International Business Mode of Lenovo

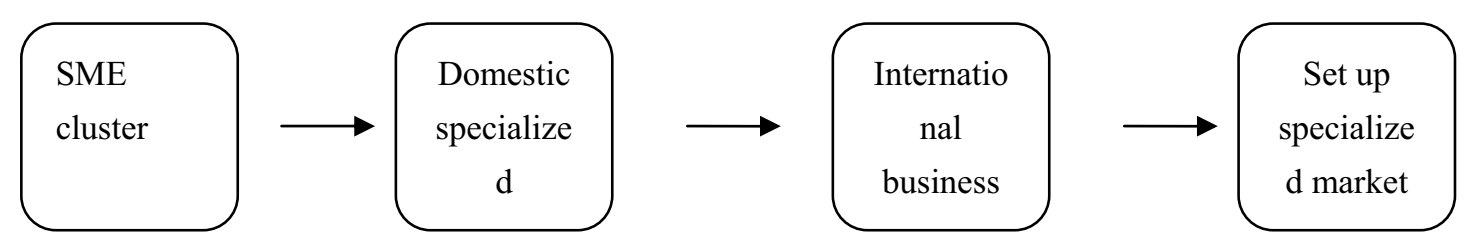

Figure 4. The International Business Mode of Zhejiang private SME 